\title{
INVESTIGATION FOR SIGNS OF BENZENE INTOXICATION IN WORKERS USING AEROPLANE DOPE AND RUBBER SOLVENTS
}

\author{
BY \\ DONALD HUNTER, REGINALD MILTON and KENNETH M. A. PERRY \\ From the Department for Research in Industrial Medicine (Medical Research Council), The London Hospital,
}

\author{
H. J. BARRIE
}

From the Pathology Department, Sheffield University, and

J. F. LOUTIT and T. S. MARSHALL

From the South-West London Blood Transfusion Depot

The purpose of the investigation was to assess the evidence of benzene poisoning in workers handling aeroplane dope and the rubber solvents used in covering self-sealing petrol tanks. These substances contain benzene in variable quantities. The amount depends on the supplies of xylene, toluene, benzene and other solvents available, though the amount of benzene in aeroplane dope, in spite of the difficulties of war conditions, does not exceed 15 per cent. In the case of the industrial rubber solvents the amount of aromatic hydrocarbons is not more than 5 per cent.

H. J. Barrie visited six factories in Yorkshire. He interviewed and noted the age, number of children, length of time in present employment, type of previous occupation, and symptoms of 183 women and 53 men employed in dope shops. A similar number of workers of the same sex and economic group who were employed in the same factories, but who were not exposed to dope, were examined and used as controls. On each group he made full blood counts, and obtained samples of urine from each of the workers for the estimation of the inorganic-total sulphate ratio. J. F. Loutit and T. S. Marshall in Surrey made similar investigations on a smaller scale in two factories. They examined 44 women and 21 men; but did not examine controls or collect urine samples, as no abnormality was apparent and they were engaged on other pressing work. D. Hunter and K. Perry also made investigations at eight factories in Hertfordshire on 164 women and 43 men using aeroplane dope, and 193 women using rubber solvents, and examined a similar group of 174 women as controls. R. Milton obtained samples of urine from 100 women in factories, and from 100 women hospital patients as controls, and investigated the inorganic-total sulphate ratio. $\mathrm{He}$ also made investigations into the amount of benzene present in the atmosphere, both in the general shop and where specific jobs of short duration were being carried out, such as spraying the inside of cockpits and the under surface of wings in the horizontal position. Unfortunately, through circumstances beyond our control, the investigation of blood and concentration of benzene in the atmosphere did not coincide, and while the composition of the rubber solvent did not change, there is reason to believe that the amount of benzene in the dope was substantially less at the time of the atmosphere estimations than that present at the time of the blood counts.

\section{Review of Literature}

Before describing the results of these investigations. a short review of the literature of benzene (or benzol) will be given. Schrenk, Yant, Pearce and Sayers (1940) have shown that the response of dogs and guinea-pigs exposed to crude and commercial benzols is characteristic of benzene poisoning and the pathological effect is due to the benzene content of the solvent used and not to impurities. Toluene and higher homologues of benzene have no such action, provided they contain no benzene. Commercial toluol may contain up to 15 per cent. benzene, and this may explain the serious toxic effects in industrial workers which have been attributed to the inhalation of toluene. The risk of chronic poisoning with this group of solvents depends therefore on their benzene content. Massive exposure to benzene results in acute poisoning with symptoms of excitement, incoherent speech, flushed face, headache, giddiness, nervousness, insomnia, nausea, paraesthesiae in hands and feet, and fatigue with ultimate narcosis and death. This syndrome is not likely to arise under conditions considered in this paper. Chronic benzene poisoning, on the other hand, is an important condition, and no satisfactory method has been devised so far to detect it in its earliest stage. It is accepted, however, that repeated exposure to benzene may cause poisoning mani- 
fested by severe and often fatal anaemia resulting from its toxic effect on the bone marrow.

The early work on chronic benzene poisoning by Santesson (1897) and Selling (1910 and 1916) established the conception of a severe and usually fatal aplastic anaemia. They considered that the effect on haemopoiesis was progressive, affecting first the platelets, then the granular leucocytes, and finally the red cells. It was thought that a diagnosis of benzene poisoning was not justified unless there was an aplastic anaemia associated with a granulocytopenia, the latter being the more important for diagnosis. The cases invariably showed purpuric haemorrhages, bleeding gums, epistaxis or menorrhagia. The spleen was never enlarged, and the bone marrow was always aplastic. Young women were more susceptible than men to the vapour of benzene and a concentration in the air of 100 parts per million or less was considered safe. Later work on manifest poisoning made it clear that anaemias caused by benzene may not follow one pattern. They may be macrocytic or microcytic, and the different components of the blood may be affected in varying degree.

Detailed studies upon 89 workmen exposed to benzene were made in 1939 by F. T. Hunter. In the same year Erf and Rhoads reported the findings in 9 patients poisoned by benzene, and Mallory, Gall and Brickley reported on 19 . The last-mentioned workers found the picture in the bone marrow to vary from severe hypoplasia to the most extreme hyperplasia. Hyperplasia was commoner, and they even recorded extramedullary haemopoiesis. Hyperplastic reactions were more common in males and were only found in patients after prolonged exposure, whereas hypoplasia followed either short or long contact and was more common in females. At necropsy the spleen was often enlarged, lymph nodes were prominent and dusky pink on cut section. Purpura of skin, mucous membranes and serous surfaces was often noticed. Gangrenous stomatitis was present in some of the worst cases.

In the cases reported by Erf and Rhoads the haematological findings were very variable. Thus, in 9 patients the haemoglobin values ranged between 47 per cent. and 81 per cent., the red-cell count from $1,850,000$ to $4,130,000$ per cu. mm., the white-cell count between 1,750 and 6,500 per cu. mm., the platelet count from 18,000 to 150,000 per cu. mm., and the reticulocytes from 3.8 to 14 per cent. Free hydrochloric acid was found in the gastric juice of all the patients, though two were achlorhydric until histamine was injected.

There are many indications that circulating red cells may be destroyed at an abnormally rapid rate in patients poisoned with benzene. Many authors have recorded increased numbers of circulating reticulocytes, a finding which was assumed to indicate abnormally active haemopoiesis. A raised plasma-bilirubin and an increased excretion of urobilinogen in the urine has been reported. Haemosiderosis of the liver, spleen, kidneys, and bone marrow is a frequent pathological alteration, both in human beings and in experimental animals dead of benzene poisoning.

The evidence that chronic exposure to benzene produces leukaemia in human beings is still incomplete, but it is accumulating rapidly and to a volume which commands serious consideration. Penati and Vigliani (1938) were able to collect 10 cases of leukaemia in patients exposed to benzene. Several varieties of the leukaemic state have been recorded - chronic myeloid, chronic lymphatic, and acute myeloblastic. Four more cases may now be added to this list, namely, two published by F. T. Hunter, one by Mallory, Gall and Brickley, and one by Erf and Rhoads, all in 1939. One of Hunter's patients showed a typical acute leukaemia; he had been heavily exposed to benzene for four years, lightly for a further six years, and not at all for the 20 months before his illness. Mallory tells of leukaemia in a boy of 12 years who repainted his toys after taking off the old paint with a solvent found to contain benzene. Fourteen cases of leukaemia developing among the many thousands of people exposed to this solvent do not seem impressive, but they gain in significance when we bear in mind that Lignac (1932) produced leukaemia in mice poisoned with benzene. Salter (1940) suggested that the benzene in the marrow may play the role of a carcinogen and thus cause leukaemia.

Victims of benzene poisoning often constitute a small majority of the workers. A single susceptible individual may develop fatal poisoning in an environment which does not give rise even to mild poisoning in others (Ronchetti, 1922). The factors responsible for the great variations in susceptibility are unknown, but the original idea that women are more susceptible than men has been disproved (F. T. Hunter, 1939). Changes in the blood may begin from two days to one month after the first exposure and may progress or develop after exposure has ceased.

Death may occur within three weeks of the onset of symptoms. The case mortality rate is as high as 10 per cent. Occasionally a severe case ends in recovery. Hayhurst and Neiswander (1931) recorded a case in a rubber worker in whom the red cells were 900,000 per cu. mm., haemoglobin 10 per cent., white cells 850 per cu. mm., bleeding time more than 25 minutes, and platelets 100,000 per cu. mm. Treatment by blood transfusion and iron was followed by recovery, and three and a half years later the blood count was normal except for slight granulocytopenia.

If the severe progressive anaemia of manifest poisoning may show such variations in type, it is not surprising to find that the claims in regard to the haematological signs of early poisoning are even more diverse. In most cases leucopenia has been regarded as the most reliable sign of early or occult poisoning, but nearly every abnormality of the blood picture has been cited. Many investigators apparently have not realized the necessity of strict controls to the group they have studied. From experience of a group of 267 rotogravure workers of mixed European descent who worked in a New York cellar exposed to concentrations of benzene vapour up to 1,000 parts per million, Greenburg, Mayers, Goldwater and Smith (1939) deprecated reliance on the leucocyte count as a rapid means of detecting cases of poisoning; leucopenia, they said, is more often found in severe than in early cases. They regarded a reduction in the number and an increase in the size of the red cells as earlier and more sensitive signs of poisoning, and they looked with suspicion on macrocytosis in a benzene worker even in the absence of other abnormalities.

Eosinophilia, erythrocytosis, and leucocytosis occasionally accompany the condition, but rarely stand as isolated phenomena. Of the 98 cases 
recorded by Greenburg and his colleagues (1939), 24 had an eosinophilia count over 3 per cent., 7 had a red cell count over $5,200,000$ per cu. mm., and 28 had a white cell count over 9,900 per cu. $\mathrm{mm}$.

Recently Hamilton-Paterson and Browning (1944) claimed that workers exposed to benzene from rubber solvents showed a significant leucopenia with a relative lymphocytosis. However, they did not estimate how much benzene was present in the air. If the conditions were similar to those we are describing the amount would be insignificant, and therefore these changes could not be attributed to benzene.

Apart from haematology, Schrenk, Yant and Sayers (1936) found that after exposure of men and animals to benzol, there occurred an increase in the organic sulphate excreted in the urine. The ratio of inorganic to total sulphate, usually about 80 per cent., was thereby lowered. They compared their findings in the urine with blood counts on the same patients. They also estimated the amount of benzene in the atmosphere to which these individuals were exposed and found that all three were correlated. They concluded, however, that the sulphate ratio in the urine was a more accurate guide to exposure than was the blood count.

\section{Atmosphere Concentrations of Benzene}

The environmental study in connection with this problem has been carried out in two factories using rubber solvents, and in seven using aeroplane dopes, lacquers and thinners. In the case of the rubber solvent factories, the employees were engaged in hand brushing rubber solutions on to large surfaces, allowing the solvent to evaporate until the tacky stage, and then covering with materials to give adhesion.

The solvents used contain 5 per cent. benzene and this partly evaporated and partly permeated into the rubber materials. The tendency to a definite evaporation gradient was avoided by the ventilation system which brought a continuous current of warm air from above directly on to the evaporating surface, and out of the shop at floor level. By this means it was possible to avoid local high concentrations of benzene. The ventilation systems in these factories have been noted, and with the air change rate provided it was theoretically possible to have a continuous benzene concentration of 20 parts per million throughout the whole air space, if it was assumed that all the solvent used evaporated. This figure was obtained from the data given in Table 1 by calculating the volume of solvent which would be present in the total air volume if all the solvent evaporated. The benzene concentration will be 5 per cent. of this figure. Many estimations of the benzene concentration at different points in these factories were made, using a method (Milton 1945) which is specific for benzene. It has been shown that the concentration was remaikably consistent at the working level, be this near to the operator's mouth, between operation benches, or near the exhaust fans at ground level.

Air samples were taken over long periods in order to obtain a comprehensive knowledge of the average hazard to which the worker was exposed, because it was considered that this represented a more accurate picture of the environment than the statistical average of a number of snap samples.

As will be seen on reference to Table 1, the benzene concentration in these factories never exceeded 3 parts per million at any time, and in view of the large amount of the solvent used, and the manner in which it evaporated from large areas constantly throughout the day, this is a proof of the effectiveness of the ventilation system.

The situation in dope shops of aeroplane factories was not so straightforward since the work tended to be intermittent, and in consequence the concentration of solvent in the atmosphere varied between wide limits throughout the day. Moreover, there were local conditions of work distribution, shop

TABLE 1

ATMOSPHERE CONDITIONS IN FACTORIES USING RUBBER SOLVENTS

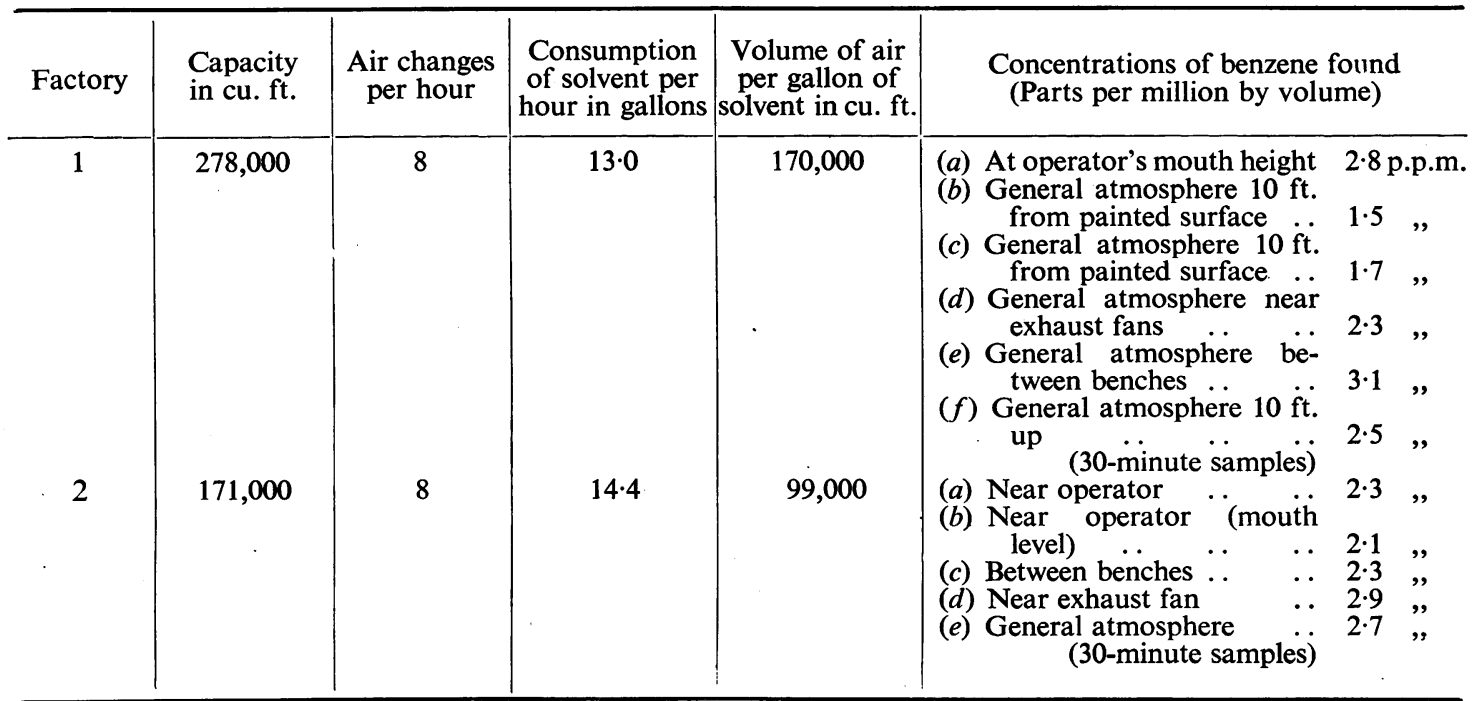


layout, and ventilation which affected the operational hazard. An environmental study was made in seven dope shops all having different conditions. The work consisted of $(a)$ hand doping, i.e. brushing cellulose dope on to aircraft parts and covering with linen, and (b) spraying cellulose paint on the wings and the fuselage. Doping was carried out largely by women who constantly stand over the evaporating surface as they work. Spraying was usually carried out by men, and was rarely continuous, time being allowed for a surface to dry before a further coat was applied. In the vicinity of the spray gun high concentrations of paint occurred in the form of mists, and although workers were provided with gauze particulate respirators these were rarely used, partly because of disinclination and partly because they were ineffective. They were, of course, useless against vapours. A number of coloured paints of varying solvent content were used. Towards the end of 1943 benzene as a basic solvent was practically eliminated in these factories and xylene substituted. The xylene content of the paints varied from 6 to 60 per cent. according to the type, and the thinners sometimes contained up to 90 per cent. of xylene. Therefore the benzene found in the atmosphere was due either to impurities in the

TABLE 2

ATMOSPHERE CONDITIONS IN AIRCRAFT DOPE SHOPS

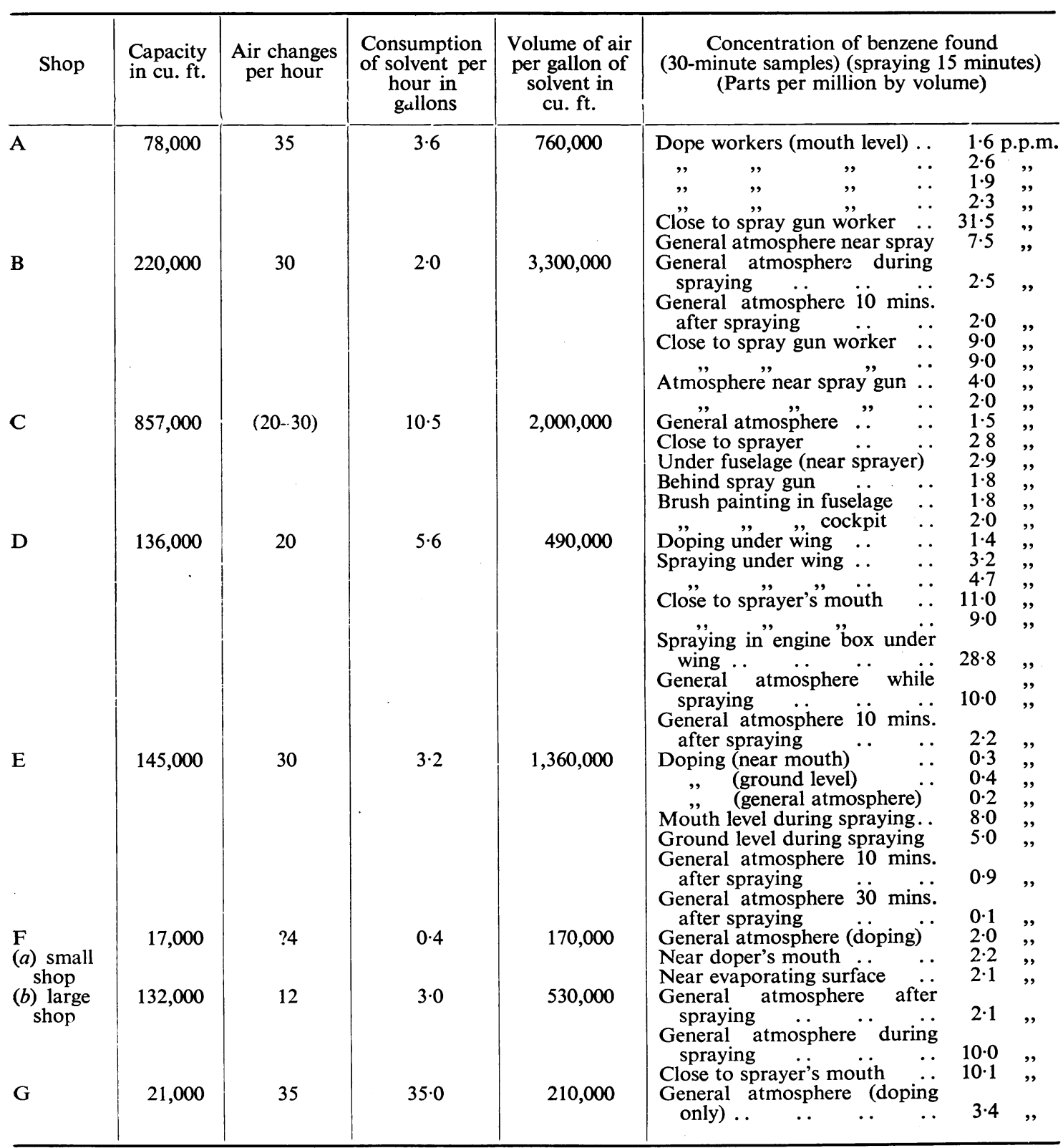


solvents or to an occasional paint which contained benzene. The supplies of solvents available was also a factor in the composition of the paints, and occasional reversions to benzene formulae were made. Although toluene was not used as a solvent, it nevertheless was demonstrated in the atmosphere, presumably arising from an impurity in the solvent.

As this investigation was concerned with the benzene hazard the concentrations of xylene and toluene were not measured. In some of the samples taken close to the sprayer there is reason to believe that the concentration of xylene was at least ten times that of benzene.

As in the case of the rubber solvent investigation, air sampling was carried out at many points in each of the factories, and wherever possible at least halfhourly samples were made to obtain average concentrations. Spraying was rarely more than a fifteen minute job, and the peak concentration was obtained in order to compare this with the general atmosphere in the dope shops. The temperature in these factories was maintained between $65^{\circ}$ and $75^{\circ} \mathrm{F}$., this being the optimum working range, and the ventilation was of the forced type with very frequent air changes. Among the factors which affected ventilation was the layout of the shop. In one factory aircraft wings stood with their lateral axes in a vertical plane, with forced ventilation bringing air in at roof height, passing on each side of the wing, and out through slats in the floor. Here the concentrations were very low. In another factory the wings were stood on trestles, and this made the sprayer work in box-like conditions under the wings, giving rise to temporary local high concentrations of solvents. In some factories hangar doors were frequently opened, and this obviously had a lowering effect on the concentrations found.

In general the benzene concentration in the atmosphere of these shops throughout the day was of the order of 3 parts per million. During spraying the general atmosphere concentration rose to about 10 parts per million. Close to the doper the concentration was usually of the order of 2-3 parts per million, but by the sprayer's mouth during the operation this was of the order of 10 parts per million. In specific jobs, e.g. spraying in engine boxes under the wing, the concentration was as high as 30 parts per million, although in this particular case we believe that a paint with 12 per cent. benzene was used. The details of these investigations are set out in Table 2. These were benzene concentrations from the use of paints and dopes in which the benzene was usually an impurity, xylene being the basic solvent. Since the vapour pressure of xylene is so much lower than benzene, it is probable that during doping operations the concentration of this solvent was low, whereas during spraying it was possibly as high as $100-200$ parts per million.

Spraying was, however, intermittent, and this concentration could not have been maintained for long in view of the frequent air changes in the shops brought about by the ventilation systems.

Details of conditions such as cubic capacity of shop, air changes per hour and quantity of dope used in the dope shops examined in Yorkshire and in Surrey are given in Tables 3 and 4 respectively.
TABLE 3

CONDITIONS IN FACTORIES IN YORKSHIRE

\begin{tabular}{c|c|c}
\hline Factory & Capacity in cu. ft. & Air changes $/ \mathrm{hr}$. \\
\hline $1(a)$ & 652,392 & - \\
$2(b)$ & 6,084 & - \\
2 & 7,280 & - \\
4 & 9,100 & 15 \\
$5(a)$ & 10,000 & 30 \\
$(b)$ & 170,135 & 30 \\
$(c)$ & 154,176 & - \\
6 & 42,275 & - \\
$7(a)$ & 3,940 & 30 \\
$(b)$ & 17,000 & 30 \\
$(c)$ & 229,400 & 30 \\
$(d)$ & 72,100 & 42,200 \\
\hline
\end{tabular}

TABLE 4

CONDITIONS IN FACTORIES IN SURREY

\begin{tabular}{|c|c|c|c|}
\hline Factory & $\begin{array}{l}\text { Capacity } \\
\text { in cu. ft. }\end{array}$ & Air changes/hr. & $\begin{array}{c}\text { Consump- } \\
\text { tion of } \\
\text { solvent } / \mathrm{hr} \text {. } \\
\text { (in galls.) }\end{array}$ \\
\hline 2 (No. 1 shop) & $\begin{array}{l}500,000 \\
151,200\end{array}$ & 5 (no spraying & $\begin{array}{r}12 \cdot 5 \\
4 \cdot 0\end{array}$ \\
\hline (No. 2 shop) & 177,260 & $\begin{array}{l}10 \text { (brush and } \\
\text { spray on } 2 \\
\text { fuselage only) }\end{array}$ & $4 \cdot 0$ \\
\hline
\end{tabular}

Age and Sex Distribution

The age and sex distribution of the workers examined in the group of factories in Hertfordshire were as follows :-

Females

Ages $\quad 18-29 \quad 30-39 \quad 40-49 \quad 50-59 \begin{gathered}60 \\ \text { and Total }\end{gathered}$

\begin{tabular}{|c|c|c|c|c|c|c|}
\hline & & & & & & \\
\hline Controls & 126 & 27 & 9 & 2 & - & 164 \\
\hline Dope workers.. & 102 & 39 & 22 & 9 & 2 & 17 \\
\hline Industrial rubber & 101 & 43 & 33 & 16 & 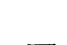 & 10 \\
\hline & & & & & & \\
\hline & & MAI & & & & \\
\hline
\end{tabular}

$\begin{array}{ccccccc}\text { Ages } & 18-29 & 30-39 & 40-49 & 50-59 & \begin{array}{c}60 \\ \text { and Total } \\ \text { over }\end{array} \\ \text { rels } & 22 & 18 & 13 & 4 & 3 & 60\end{array}$ $\begin{array}{lrrrrrrr}\text { Controls } & . . & 22 & 18 & 13 & 4 & 3 & 60 \\ \text { Dope workers.. } & 4 & 7 & 18 & 10 & 4 & 43\end{array}$

In Yorkshire and Surrey the distributions were as follows :-

Ages

Females

60

\begin{tabular}{|c|c|c|c|c|c|c|c|}
\hline & & $18-29$ & $30-39$ & $40-49$ & $50-59$ & and & \\
\hline orkshire & con- & & & & & over & \\
\hline & ame & 100 & 28 & 13 & 4 & & 145 \\
\hline workers & & 113 & 42 & 19 & 9 & 0 & 183 \\
\hline $\begin{array}{l}\text { Surrey } \\
\text { workers }\end{array}$ & dope & 29 & 11 & 4 & & & \\
\hline & & & MALES & & & & \\
\hline Ages & & $18-29$ & $30-39$ & $40-49$ & $50-59$ & $\begin{array}{l}60 \\
\text { and }\end{array}$ & \\
\hline $\begin{array}{c}\text { Yorkshire } \\
\text { trols .. }\end{array}$ & con- & 6 & 12 & 10 & 8 & over & \\
\hline Yorkshire & dope & & & & & & \\
\hline $\begin{array}{l}\text { worrey } \\
\text { urres }\end{array}$ & dope & 9 & 13 & 24 & 6 & 1 & \\
\hline workers & & 2 & 7 & 6 & 5 & 1 & 21 \\
\hline
\end{tabular}


Blood Findings in Present Investigation

In view of these findings of the concentration of benzene in the atmosphere, it was not to be expected that any changes would be found in the blood counts or inorganic-total sulphate ratio in the urine of these workers. Many of them complained of vague symptoms such as lassitude, nausea, headache and fatigue, but these are just as likely to be caused by the other constituents of the dope such as butyl acetate; and in those between the ages of 35 and 50 menorrhagia was not uncommon, but this symptom is fairly widespread in the general population between those ages. The workers were split up into several groups for the purpose of plotting frequency distribution curves and for statistical analysis (see Table 5). They were first divided into male and female. The females included 145 controls from Yorkshire and 164 controls from Hertfordshire with 183 dope workers from Yorkshire, 174 from Hertfordshire, 44 from Surrey, and 193 rubber solvent workers from the London area and Portsmouth. The male group consisted of 38 controls from Yorkshire, 60 controls from a machine shop and 43 dope workers from Hertfordshire, 53 from Yorkshire, and 21 from Surrey. The haemoglobin was estimated, at the London Hospital, by a photo-electric cell after conversion to alkaline haematin; 100 per cent. is equivalent to $13.8 \mathrm{gm}$. of haemoglobin per 100 c.c. of blood. At the S.W. London Blood Transfusion Centre and in Yorkshire it was estimated by Haldane's method in accordance with a procedure laid down by the M.R.C. sub-committee on haemoglobin; 100 per cent. is equivalent to $14.8 \mathrm{gm}$. of haemoglobin per 100 c.c. of blood. In the case of the women, the frequency distribution curves for red cells, haemoglobin, total leucocytes and total polymorphs are similar in all the groups, and there is no difference of any statistical significance in the figures. Even before the war doping was usually regarded as a woman's occupation, and therefore the group of male workers is small, but they had usually been engaged on the work for more than twenty years. They complained of no symptoms, showed no abnormal physical signs, and scorned the idea that there could possibly be a hazard in doping. The frequency distribution curves for the red blood cells and haemoglobin showed no deviation and there was no difference of statistical significance between the figures. However, the curves for the total white cells and total polymorphs showed a shift to the left. The numbers of workers concerned are so small that it is not possible to derive from them any figures of statistical value.

From this material, therefore, it is not possible to arrive at any conclusion as to what early changes may be expected in the blood count from mild benzene intoxication, or to offer any advice or opinion as to whether leucopenia or relative lymphocytosis is a danger signal. No change was seen in any individual which could be attributed without doubt to benzene intoxication in a highly susceptible

TABLE 5

STATISTICAL ANALYSIS OF THE BLOOD INVESTIGATIONS IN WOMEN WORKERS

\begin{tabular}{|c|c|c|c|c|c|c|c|}
\hline & & & $\begin{array}{l}\text { No. in } \\
\text { sample }\end{array}$ & Mean & $\begin{array}{l}\text { Standard } \\
\text { deviation }\end{array}$ & $\begin{array}{l}\text { Difference between } \\
\text { mean and mean } \\
\text { of controls }\end{array}$ & $\begin{array}{c}\text { Standard } \\
\text { error }\end{array}$ \\
\hline $\begin{array}{l}\text { HAEMOGLOBIN. } \\
\text { Hertfordshire controls } \\
\text { Hertfordshire dope worker } \\
\text { Rubber solvent workers } \\
\text { Yorkshire controls .. } \\
\text { Yorkshire dope workers } \\
\text { Surrey dope workers }\end{array}$ & $\begin{array}{l}\ldots \\
\cdots \\
\cdots \\
\cdots\end{array}$ & $\begin{array}{l}\cdots \\
\cdots \\
\cdots \\
\cdots \\
\cdots\end{array}$ & $\begin{array}{r}164 \\
174 \\
193 \\
177 \\
177 \\
43\end{array}$ & $\begin{array}{l}92 \cdot 8 \\
91 \cdot 5 \\
94 \cdot 4 \\
89 \cdot 5 \\
92 \cdot 7 \\
89 \cdot 8\end{array}$ & $\begin{array}{r}11 \cdot 675 \\
10 \cdot 120 \\
9 \cdot 735 \\
10 \cdot 450 \\
10 \cdot 340 \\
11 \cdot 15\end{array}$ & $\begin{array}{r}-\overline{1 \cdot 3} \\
+1 \cdot 6 \\
+\overline{3 \cdot 2} \\
+0 \cdot 3\end{array}$ & $\begin{array}{l}1 \cdot \overline{19} \\
1 \cdot 15 \\
1 \cdot \overline{11} \\
0 \cdot 95\end{array}$ \\
\hline $\begin{array}{l}\text { RED CELLS. } \\
\text { Hertfordshire controls } \\
\text { Hertfordshire dope worker } \\
\text { Rubber solvent workers } \\
\text { Yorkshire controls .. } \\
\text { Yorkshire dope workers } \\
\text { Surrey dope workers }\end{array}$ & $\begin{array}{l}\ldots \\
\cdots \\
\cdots \\
\cdots\end{array}$ & $\begin{array}{l}\cdots \\
\cdots \\
\cdots \\
\cdots \\
\cdots\end{array}$ & $\begin{array}{r}164 \\
174 \\
193 \\
172 \\
177 \\
44\end{array}$ & $\begin{array}{l}4 \cdot 963 \\
4 \cdot 953 \\
5 \cdot 078 \\
4 \cdot 85 \\
4 \cdot 76 \\
4 \cdot 91\end{array}$ & $\begin{array}{l}0 \cdot 435 \\
0 \cdot 475 \\
0 \cdot 403 \\
0 \cdot 369 \\
0 \cdot 423 \\
0 \cdot 309\end{array}$ & $\begin{array}{r}-\overline{0.010} \\
+0.115 \\
-\overline{0.09} \\
+0.06\end{array}$ & $\begin{array}{l}0 . \overline{048} \\
0.045 \\
\overline{0 . \overline{424}} \\
0.538\end{array}$ \\
\hline $\begin{array}{l}\text { WHITE CELLS. } \\
\text { Hertfordshire controls } \\
\text { Hertfordshire dope worker } \\
\text { Rubber solvent workers } \\
\text { Yorkshire controls .. } \\
\text { Yorkshire dope workers } \\
\text { Surrey dope workers }\end{array}$ & $\begin{array}{l}\ldots \\
\cdots \\
\cdots \\
\cdots\end{array}$ & $\begin{array}{l}\cdots \\
\cdots \\
\cdots \\
\cdots \\
\cdots\end{array}$ & $\begin{array}{r}165 \\
173 \\
192 \\
123 \\
180 \\
44\end{array}$ & $\begin{array}{l}6 \cdot 985 \\
6 \cdot 945 \\
7 \cdot 285 \\
8 \cdot 836 \\
9 \cdot 095 \\
7 \cdot 245\end{array}$ & $\begin{array}{l}2 \cdot 13 \\
2 \cdot 48 \\
2 \cdot 42 \\
2 \cdot 99 \\
3 \cdot 81 \\
2 \cdot 35\end{array}$ & $\begin{aligned} & \overline{0.04} \\
&+ 0.30 \\
&+ \overline{0.259} \\
&-1 \cdot 591\end{aligned}$ & $\begin{array}{l}0 . \overline{25} \\
0 \cdot 24 \\
0 . \overline{37} \\
0.41\end{array}$ \\
\hline $\begin{array}{l}\text { POLYMORPHS. } \\
\text { Hertfordshire controls } \\
\text { Hertfordshire dope workers } \\
\text { Rubber solvent workers } \\
\text { Yorkshire controls .. } \\
\text { Yorkshire dope workers } \\
\text { Surrey dope workers }\end{array}$ & $\begin{array}{l}\ldots \\
\mathrm{rs} \\
\ldots \\
\ldots \\
\ldots\end{array}$ & $\begin{array}{l}\ldots \\
\ldots \\
\ldots \\
\ldots \\
\ldots\end{array}$ & $\begin{array}{r}145 \\
157 \\
182 \\
14 \\
17 \\
43\end{array}$ & $\begin{array}{l}3 \cdot 861 \\
3 \cdot 985 \\
4 \cdot 176 \\
4 \cdot 638 \\
5 \cdot 259 \\
4 \cdot 007\end{array}$ & $\begin{array}{l}1 \cdot 55 \\
1 \cdot 61 \\
1 \cdot 61 \\
1 \cdot 75 \\
2 \cdot 461 \\
1 \cdot 529\end{array}$ & $\begin{array}{r} \\
+\overline{0.124} \\
+0.315 \\
+\overline{0.621} \\
-0.631\end{array}$ & $\begin{array}{c}\overline{0 \cdot 182} \\
0 \cdot 176 \\
\overline{0.755} \\
0.872\end{array}$ \\
\hline
\end{tabular}


person. This is not surprising since workers in the group examined were not exposed to concentrations of benzene in the atmosphere which would be expected to give rise to poisoning.

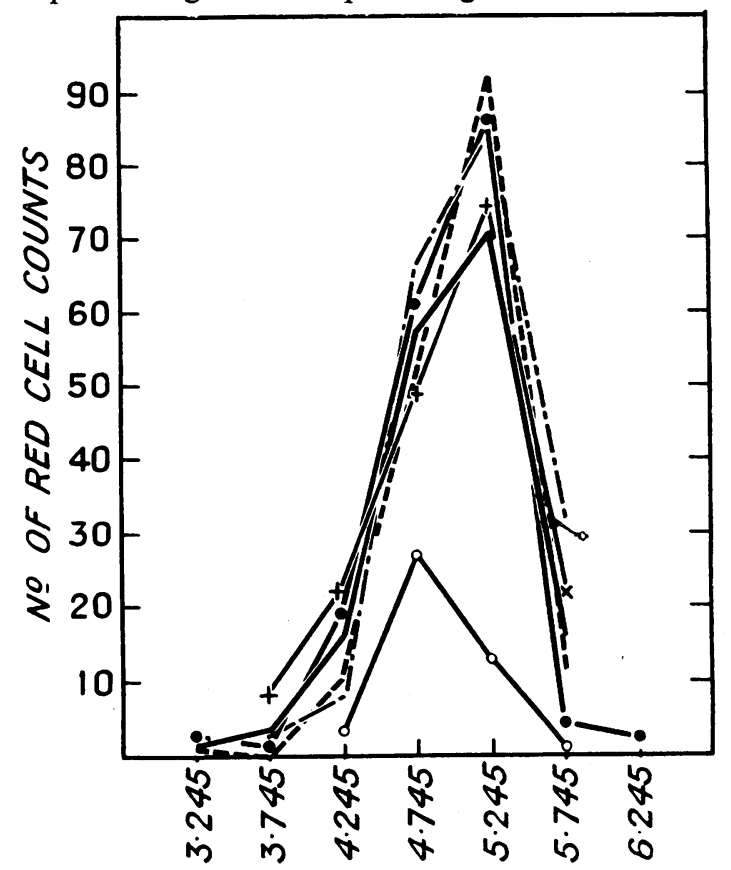

RED CELLS IN MILLIONS per c.mm.

Fig. 1.-Frequency distribution curve of red blood cells in women.

See key on Figure 9. Hertfordshire controls (164); Dope workers (174). Rubber solvent workers (193). Yorkshire controls (H. J. B.) (172); Dope workers (177). Surrey dope workers (J. F. L.) (44)-line and circles.

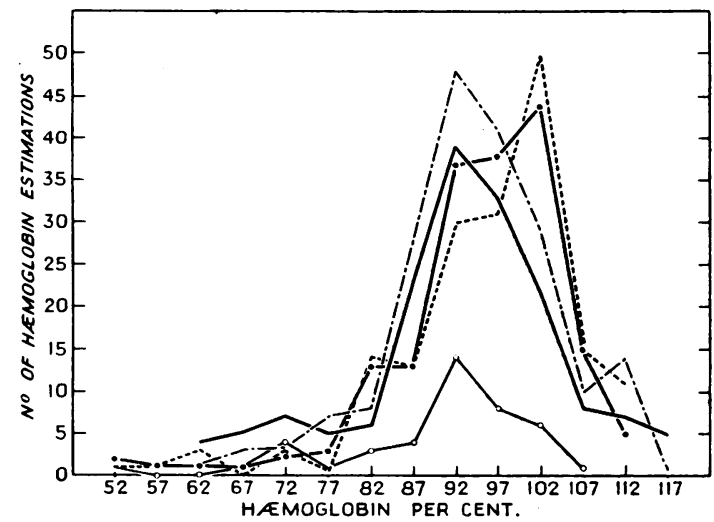

Fig. 2.-Frequency distribution curve of haemoglobin in women.

Hertfordshire controls (164); Dope workers (174) Rubber solvent workers (193). Yorkshire controls (177); Dope workers (177). Surrey dope workers (43)-line and circles.

\section{Inorganic-Total Sulphate Ratio in Urine}

This study of the effect of benzene on aircraft workers has also involved an investigation of the conjugated sulphate excretion in the urine of the workers. It has been shown by Schrenk, Yant and Sayers (1936) on experiments with dogs that benzene absorbed into the blood stream via the lungs is partly excreted in the urine as ethereal sulphate. This increase in conjugated sulphate occurs at the expense of the inorganic sulphate normally present, and so the percentage of inorganic sulphate of the total sulphate is diminished. This ratio is proposed as being a reliable index of the degree of benzene intoxication. A snap sample of urine is taken to carry out the test, since it concerns a ratio of one concentration to another, and not an absolute excretion of a particular substance.

This test was carried out on about 94 workers with rubber solvents, and 130 workers in dope shops (see Table 6). Comparative tests were made with 100 controls taken at random from hospital patients. The method used for the estimation was that of Milton (1932), and consists of the nephelometric estimation of a barium sulphate suspension, prepared under rigid conditions and in the presence of a protective colloid. Frequency distribution curves have been drawn and it is seen that the curves for the three groups are similar. The statistical analysis of the figures shows no difference of any significance.

In Yorkshire sulphate estimations were made on 178 dope workers and on 72 of the controls by the gravimetric method of Folin (1905) (Table 6). The

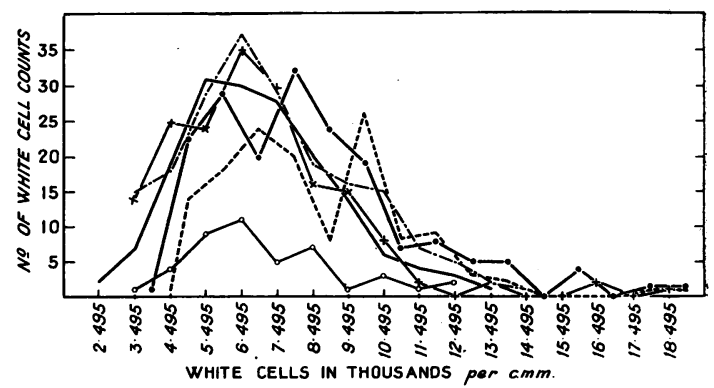

FIG. 3.-Frequency distribution curve of total white cells in women.

Hertfordshire controls (165); Dope workers (173). Rubber solvent workers (192). Yorkshire controls (123); Dope workers (180). Surrey dope workers (44)-line and circles.

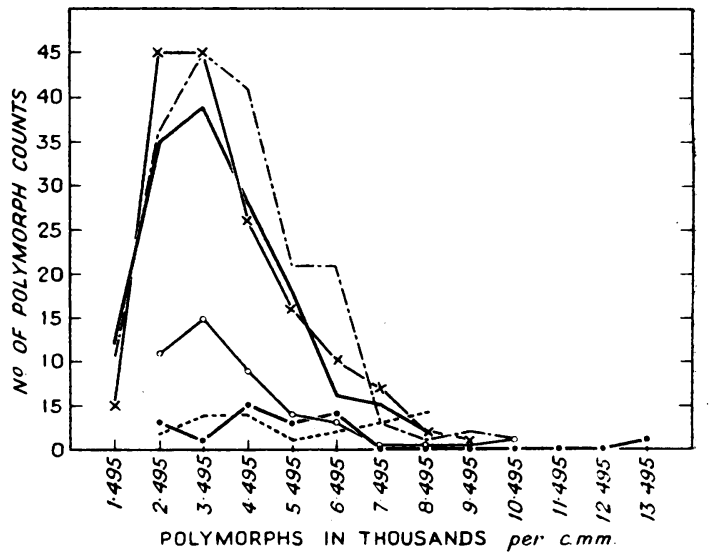

FIG. 4.-Frequency distribution curve of total polymorphs in women.

Hertfordshire controls (145); Dope workers (157). Rubber solvent workers (182). Yorkshire controls (14); Dope workers (17). Surrey dope workers (43)-line and circles. 
specimens were collected in the afternoon so that any exposure to benzol in the morning might influence the sulphate ratio. The frequency distribution curve of these values is shown in Fig. 9; 12 of the dope workers had an inorganic sulphate ratio between 60 and 70 per cent. and 7 of these came from one factory. The remaining 5 were scattered throughout other factories. In general the distribution of sulphate ratios in the dope workers appears slightly lower than those in the control group, but as will be seen from the statistical analysis, there is no difference which is significant.

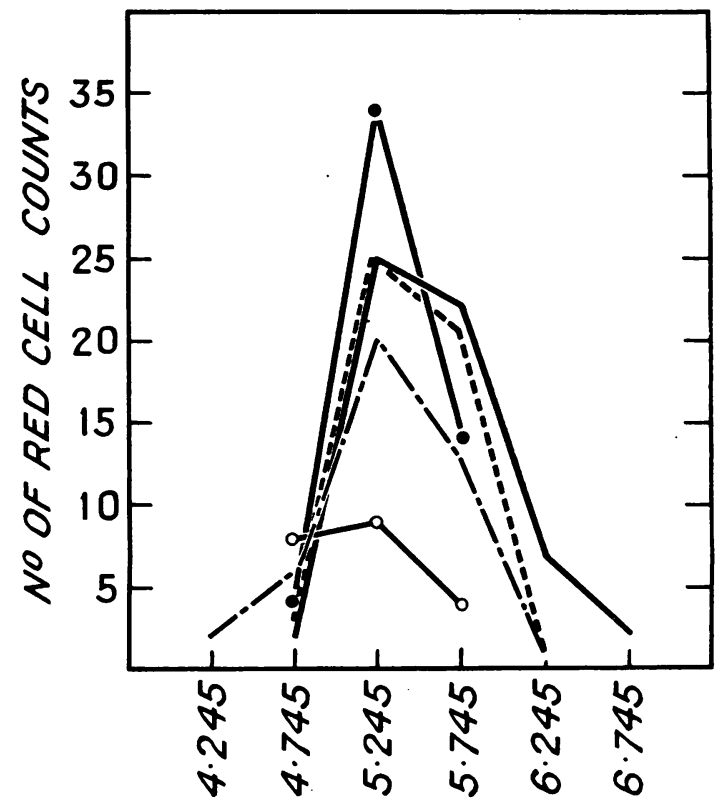

RED CELLS IN MILLIONS per c.mm.

Fig. 5.-Frequency distribution curve of red blood cells in men.

Hertfordshire controls (58); Dope workers (42). Yorkshire controls (50); Dope workers (52). Surrey dope workers (21)-line and circles.

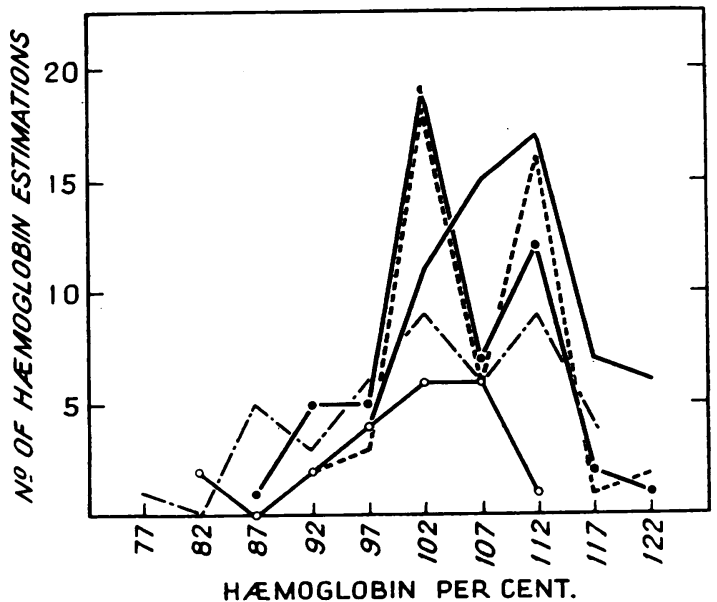

FIG. 6.-Frequency distribution curve of haemoglobin in men.

Hertfordshire controls (60); Dope workers (43). Yorkshire controls (50); Dope workers (52). Surrey dope workers (21)-line and circles.



FIG. 7.-Frequency distribution curve of total white cells in men.

Hertfordshire controls (60); Dope workers (43). Yorkshire controls (54); Dope workers (54). Surrey dope workers (21)-line and circles.

TABLE 6.-INORGANIC-TOTAL SULPHATE RATIO IN URINE

\begin{tabular}{|c|c|c|c|c|c|c|c|c|c|c|c|}
\hline & \multirow{2}{*}{$\begin{array}{l}\text { No. in } \\
\text { sample }\end{array}$} & \multicolumn{10}{|c|}{ Per cent. total number of workers } \\
\hline & & $100 \% *$ & $95 \%$ & $90 \%$ & $85 \%$ & $80 \%$ & $75 \%$ & $70 \%$ & $65 \%$ & $60 \%$ & $55 \%$ \\
\hline $\begin{array}{ll}\text { Hertfordshire controls } & . . \\
\text { Hertfordshire dope workers } & \ldots \\
\text { Rubber solvent workers .. } & \ldots \\
\text { Yorkshire controls (H. J. B.) } \\
\text { Yorkshire dope workers (H. J. B.) }\end{array}$ & $\begin{array}{r}100 \\
130 \\
94 \\
72 \\
178\end{array}$ & $\begin{array}{r}3 \cdot 0 \\
0 \cdot 7 \\
3 \cdot 1 \\
10 \cdot 0 \\
4 \cdot 5\end{array}$ & $\begin{array}{r}15 \cdot 0 \\
12 \cdot 3 \\
16 \cdot 0 \\
11 \cdot 2 \\
7 \cdot 5\end{array}$ & $\begin{array}{l}37 \cdot 0 \\
30 \cdot 0 \\
21 \cdot 1 \\
33 \cdot 3 \\
22 \cdot 0\end{array}$ & $\begin{array}{l}20 \cdot 0 \\
29 \cdot 2 \\
27 \cdot 3 \\
16 \cdot 5 \\
14 \cdot 5\end{array}$ & $\begin{array}{l}14 \cdot 0 \\
10 \cdot 0 \\
23 \cdot 2 \\
16 \cdot 5 \\
28 \cdot 0\end{array}$ & $\begin{array}{l}6 \cdot 0 \\
9 \cdot 5 \\
2 \cdot 1 \\
5 \cdot 5 \\
7 \cdot 5\end{array}$ & $\begin{array}{r}3 \cdot 0 \\
3 \cdot 7 \\
1 \cdot 4 \\
7 \cdot 0 \\
10 \cdot 0\end{array}$ & $\begin{array}{l}1 \cdot 0 \\
2 \cdot 3 \\
2 \cdot 1 \\
0 \cdot 0 \\
3 \cdot 0\end{array}$ & $\begin{array}{l}1 \cdot 0 \\
2 \cdot 3 \\
2 \cdot 1 \\
\frac{1}{3 \cdot 0}\end{array}$ & $\begin{array}{l}0.0 \\
0.0 \\
1.6 \\
- \\
0.0\end{array}$ \\
\hline
\end{tabular}

Statistical Examination of Results

\begin{tabular}{|c|c|c|c|c|c|}
\hline & $\begin{array}{l}\text { No. in } \\
\text { sample }\end{array}$ & Mean & $\begin{array}{l}\text { Standard } \\
\text { deviation }\end{array}$ & $\begin{array}{l}\text { Difference between } \\
\text { mean and mean } \\
\text { of controls }\end{array}$ & $\begin{array}{l}\text { Standard } \\
\text { error }\end{array}$ \\
\hline $\begin{array}{l}\text { Hertfordshire controls } \\
\text { Hertfordshire dope workers .. } \\
\text { Rubber solvent workers } \\
\text { Yorkshire controls (H. J. B.) } \\
\text { Yorkshire dope workers (H. J. B.) }\end{array}$ & $\begin{array}{r}100 \\
130 \\
94 \\
72 \\
178\end{array}$ & $\begin{array}{l}85 \cdot 0 \\
84 \cdot 7 \\
85 \cdot 2 \\
85 \cdot 5 \\
83 \cdot 4\end{array}$ & $\begin{array}{l}8 \cdot 25 \\
8 \cdot 1 \\
8 \cdot 43 \\
8 \cdot 17 \\
9 \cdot 26\end{array}$ & $\begin{array}{r}-\overline{0 \cdot 3} \\
+0 \cdot 2 \\
-\overline{1 \cdot 1}\end{array}$ & $\begin{array}{l}\overline{1 \cdot 07} \\
1 \cdot 14 \\
\overline{1 \cdot 19}\end{array}$ \\
\hline
\end{tabular}

* Inorganic sulphate as per cent. total sulphate $(100 \%, 95 \%, 90 \%$, etc.). 


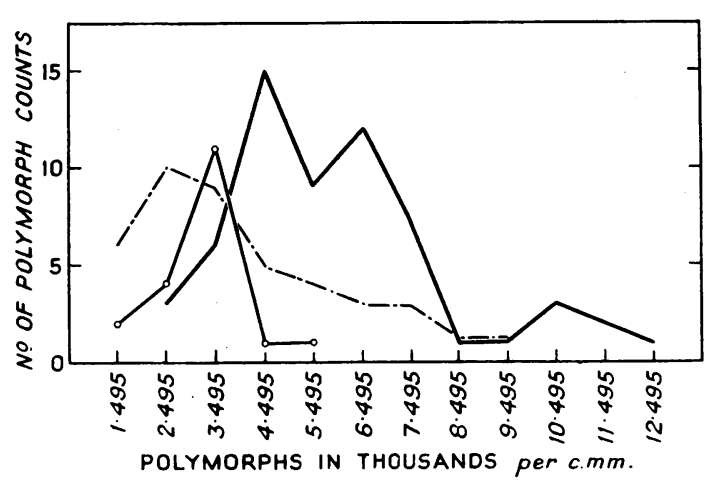

FIG. 8.-Frequency distribution curve of total polymorphs in men.

Hertfordshire controls (60); Dope workers (42). Surrey dope workers (19)-line and circles.

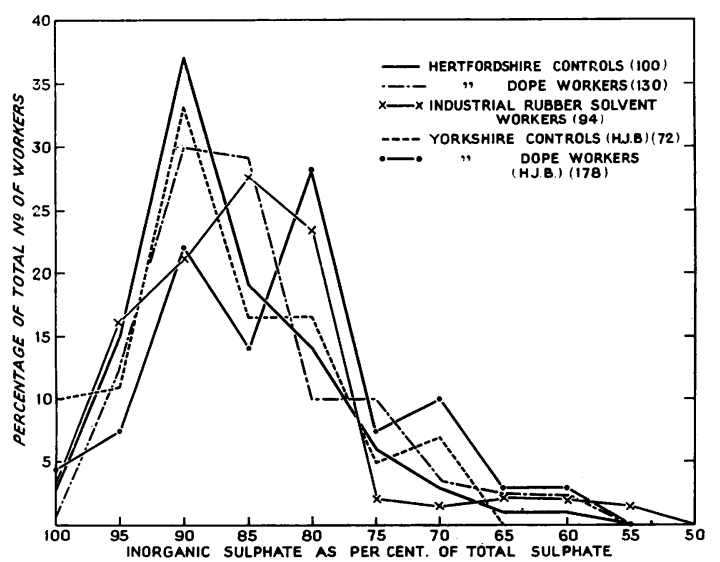

FIG. 9.-Frequency distribution curve of inorganictotal sulphate ratio in the urine.

\section{Summary}

In this investigation concentration of benzene in the atmosphere of dope shops and factories using rubber solvents did not approach toxic levels. Blood counts of workers in these factories were not significantly different from counts in a control group. No material change was found in the inorganic-total sulphate ratio in the urine of the workers. It is emphasized that, in the absence of estimations of atmosphere concentrations of benzene, blood changes alone cannot be accepted as evidence of benzene intoxication.

We are greatly indebted to Dr. D. R. Thompson, Miss Shervington and the De Havilland Aircraft Company, Ltd., without whose help the Hertfordshire part of this investigation could not have been carried out; to Dr. F. C. O. Valentine for help with this part of the haematological work; and to Dr. A. I. G. McLaughlin, H.M. Medical Inspector of Factories, and Mr. F. A. M. Vincent for their assistance with the Sheffield section of the investigation.

\section{REFERENCES}

Erf, L. A., and Rhoads, C. P. (1939). J. industr. Hyg., 21, 421.

Folin, O. (1905). J. biol. Chem., 1, 131.

Greenburg, L., Mayers, M. R., Goldwater, L., and Smith, A. R. (1939). Ibid., 21, 395.

Hamilton-Paterson, J. L., and Browning, E. (1944). Brit. med. J., 2, 349.

Hayhurst, E. R., and Neiswander, B. E. (1931). J. Amer. med. Ass., 96, 269.

Hunter, F. T. (1939). J. industr. Hyg., 21, 331.

Lignac, G. O. E. (1932). Krankheitsforsch, 9, 403.

Mallory, T. B., Gall, E. A., and Brickley, W. J. (1939). J. industr. Hyg., 21, 355.

Milton, R. (1932). Bull. Soc. chem. Biol., 14, 1447.

- (1945). Brit. J. industr. Med. (in the press).

Penati, F., and Vigliani, E. C. (1938). Rass. med. Industr., 9, 345.

Ronchetti, V. (1922). Atti Soc. lomb. Sci. med. biol., 11, 322.

Salter, W. T. (1940). New Engl. J. Med., 222, 146.

Santesson, C. G. (1897). Arch. Hyg., 31, 336.

Schrenk, H. H., Yant, W. P., Sayers, R. R. (1936). J. Amer. med. Ass., 107, 849.

- - - - - - (1936). J. industr. Hyg., 18, 448. - Pearce, S. J., and Sayers, R. R. (1940). J.

Selling, L. (1910). Johns Hopk. Hosp. Bull., 21, 33. (1916). Johns Hopk. Hosp. Rep., 17, 83. 